No $2011-22$

November

CEPII

CENTRE

D'ÉTUDES PROSPECTIVES

ET D'INFORMATIONS

INTERNATIONALES

More Bankers, More Growth?

Evidence from OECD Countries

Gunther Capelle-Blancard and Claire Labonne 


\section{TABLE OF CONTENTS}

Non-technical summary. . . . . . . . . . . . . . . . . . . . . . . . . . . 3

Abstract . . . . . . . . . . . . . . . . . . . . . . . . . . . . 3

Résumé non technique . . . . . . . . . . . . . . . . . . . . . 5

Résumé court . . . . . . . . . . . . . . . . . . . . . . . . . . . . . 6

1. Introduction . . . . . . . . . . . . . . . . . . . . . . . . . . . . . . 7

2. Measuring financial deepening . . . . . . . . . . . . . . . . . . . 8

3. Methodology . . . . . . . . . . . . . . . . . . . . . . . . 10

4. Results . . . . . . . . . . . . . . . . . . . . . . . . . . 11

5. Conclusion . . . . . . . . . . . . . . . . . . . . . . . . . 13

List of working papers released by CEPII . . . . . . . . . . . . . . . . . . . . 21 


\section{MORE BANKers, MORE GroWth? EVIDENCE FROM OECD COUNTRIES}

\section{NON-TECHNICAL SUMMARY}

Does finance spur economic growth? At the end of the 1990s, the debate seemed over. An abundant empirical literature supported a positive causal effect of finance on GDP. However, since the early 2000s, skepticism has been growing and several authors have pointed out some serious methodological problems.

The recent crisis has also altered the mindset on the supposed positive impact of finance on growth. Financial deepening theoretically spurs economic growth by facilitating capital allocation, pooling savings, sharing risk, monitoring firms and producing information. However, these effects might be offset by two factors previously neglected in the literature.

- Excessive growth of credit. An increase of credit volume - the most common proxy for financial deepening - does not mean that the financial sector fulfills its functions better (the same is true also for market capitalization). Sometimes, this is even just the opposite: an excessive growth of credit may undermine the financial system and hurt economic growth. Undoubtedly, the subprime mortgage crisis is a good example of such unproductive financial deepening.

- Misallocation of talents. The allocation of talent is understood as an important determinant of growth. During the last two decades, it is likely that the financial industry has attracted too many talents, to the detriment of others industries. During the crisis, such concern was vividly expressed, in particular by Lord Turner, the chairman of the UK's Financial Services Authority, who declared in 2009 that the financial industry had grown "beyond a socially reasonable size".

In this paper, we propose to gauge the size of the financial sector based on its inputs, rather than its outputs: more specifically, we consider two original variables: i) the number of employees in the financial sector divided by the total workforce and ii) the ratio private credit divided by the number of employees in the financial sector. Using the number of employees to assess the size of an industry is quite usual in the economic literature, but strangely not in financial economics. Our two variables alleviate both the problems of excessive growth of credit and misallocation of talents. Moreover, our data have the advantage of being available over a long period (1970-2008) for a large sample (24 OECD countries). Hence, our results are directly comparable with the bulk of evidence on the finance-growth nexus. Our methodology relies on difference and system estimators in the context of growth equation estimation. It enables us to handle endogeneity with macroeconomic data. Our results confirm that there is no clear and positive relationship between finance and growth. 


\begin{abstract}
In this paper, we reexamine empirically the finance/growth nexus. We argue that financial deepening should not only be assessed with familiar measures of financial activities outputs (e.g. credit volume), but also through its inputs (e.g. the relative number of employees in the financial industry) or the efficiency of the financial intermediation process (measured in this paper by the ratio credit volume to number of employees). Overall, our study confirms the absence of a positive relationship between financial deepening and economic growth for OECD countries over the last forty years.
\end{abstract}

JEL Classification: G20.

Keywords: $\quad$ Finance-growth nexus, optimal size of the financial sector, financial intermediation, bank efficiency, system and difference GMM. 


\section{Plus de banquiers, plus de Croissance? UNE ÉTUDE EMPIRIQUE SUR LES PAYS DE L'OCDE}

\section{RÉSUME NON TECHNIQUE}

La finance stimule-t-elle la croissance économique ? A la fin des années 1990, le débat semblait définitivement clos. Une littérature empirique abondante soutenait en effet l'idée d'une causalité positive de la finance vers le PIB. A partir des années 2000, ce consensus a commencé à se fissurer, plusieurs auteurs soulignant quelques graves problèmes méthodologiques dans l'estimation empirique des relations de causalité entre finance et croissance.

La crise récente a également modifié l'opinion générale sur ce sujet. Théoriquement, le développement du secteur financier doit avoir un impact positif sur la croissance économique en facilitant l'allocation du capital, la mise en commun de l'épargne, le partage des risques, le contrôle et la surveillance des entreprises, ainsi qu'en favorisant la production et la diffusion d'informations. Il est toutefois possible que ces effets soient compensés par deux facteurs généralement négligés dans la littérature.

- Une croissance potentiellement excessive du crédit. Une augmentation du volume de crédits l'indicateur le plus communément utilisé pour apprécier le développement des activités financières - ne signifie pas nécessairement que le secteur financier accomplisse ses fonctions de manière plus efficace (l'argument est similaire pour la capitalisation boursière). C'est même parfois tout le contraire : une croissance excessive du crédit peut nuire au système financier et à la croissance économique. La crise des subprimes en est sans aucun doute une bonne illustration.

- La mauvaise allocation des talents. L'allocation des talents est considérée comme un déterminant important de la croissance. Au cours des deux dernières décennies, le secteur financier a attiré de très nombreux jeunes diplômés, peut être au détriment des autres industries. Pendant la crise, plusieurs voix ont d'ailleurs exprimé des préoccupations à ce sujet, notamment Lord Turner, le président de la FSA (l'autorité de régulation britannique), qui n'a pas hésité en 2009 à déclarer que la taille du secteur financier au Royaume-Uni était "au-delà d'une taille socialement raisonnable".

Dans ce papier, nous proposons d'évaluer la taille du secteur financier en utilisant non pas les outputs du processus d'intermédiation financière, mais ses inputs. Précisément, nous considérons deux variables originales : i) le nombre de salariés dans le secteur de la finance rapporté au nombre total de salariés dans l'économie, tous secteurs confondus; ii) le ratio volume de crédits accordés aux agents privés sur le nombre de salariés dans le secteur de la finance. Utiliser le nombre de salariés pour apprécier la taille d'un secteur est assez usuel dans la littérature économique, mais étrangement pas en économie financière. Nos deux variables permettent de limiter les problèmes liés à la croissance potentiellement excessive des crédits et à la mauvaise allocation des talents. Nos données ont, en outre, l'avantage d'être disponibles sur une longue période (1970-2008) pour un large échantillon de pays (24 pays de l'OCDE). Nos résultats sont ainsi directement comparables avec la littérature académique standard sur les liens de causalité entre 
finance et croissance. Notre méthodologie repose sur la technique des panels dynamiques (estimateurs différence et système) appliquée aux modèles de croissance. Elle nous permet de traiter l'endogénéité des données macroéconomiques. Nos résultats confirment qu'il n'y a pas de relation claire et positive entre la finance et la croissance pour les pays développés sur les quarante dernières années.

\section{RÉSUMÉ COURT}

Dans ce papier, nous réexaminons empiriquement le lien entre finance et croissance. Nous soutenons que le développement de la sphère financière ne doit pas seulement s'apprécier par le montant des financements accordés (volume de crédits ou capitalisation boursière), mais aussi par le poids des activités financières relativement aux autres secteurs (approché ici par le nombre de salariés dans le secteur banque-finance rapporté au nombre total de salariés) ou par l'efficacité du processus d'intermédiation financière (mesurée dans cette étude par le ratio volume de crédit sur nombre de salariés). Globalement, notre étude confirme l'absence de relation positive entre la croissance du secteur financier et la croissance économique pour les pays de l'OCDE au cours des quarante dernières années.

\section{Classification JEL : G20.}

Mots clés : $\quad$ Causalité finance/croissance, taille optimale du système financier, intermédiation financière, estimateur GMM système et différence. 


\title{
MORE BANKERS, MORE GROWTH? EVIDENCE FROM OECD COUNTRIES ${ }^{1}$
}

\author{
Gunther Capelle-Blancard* \\ Claire Labonne ${ }^{\dagger}$
}

\section{INTRODUCTION}

Does finance spur economic growth? At the end of the 1990s, the debate seemed over. An abundant empirical literature supported a positive causal effect of finance on GDP (see Levine (2005) for a survey). However, since the early 2000s, skepticism has been growing (Wachtel (2003); Manning (2003)): Rousseau \& Wachtel (2002) show that finance only causes growth conditionally on inflation; Rioja \& Valev (2004) underline the sensitivity of the relationship to the level of development; Roodman (2009) considers that previous results were driven by undetected endogeneity; Rousseau \& Wachtel (2011) and Bordo \& Rousseau (2011) highlight the decline of the causal link through time.

The recent crisis has also altered the mindset on the supposed positive impact of finance on growth. Financial deepening theoretically spurs economic growth by facilitating capital allocation, pooling savings, sharing risk, monitoring firms and producing information (Levine (2005)). However, these effects might be offset by two factors previously neglected in the academic literature.

- Excessive growth of credit. An increase of credit volume - the most common proxy for financial deepening - does not mean that the financial sector fulfills its functions better (the same is true also for market capitalization). Sometimes, this is even just the opposite. As stated by Rousseau \& Wachtel (2011), an excessive growth of credit may undermine the financial system and hurt economic growth. Further, Arcand et al. (2011) have recently suggested that finance has a negative impact on growth when private credit is above a threshold estimated as $110 \%$ of GDP. Undoubtedly, the subprime mortgage crisis is a good example of such unproductive financial deepening.

- Misallocation of talents. Since Baumol (1990) and Murphy et al. (1991), the allocation of talent is understood as an important determinant of growth. Recently, Philippon (2009) and

\footnotetext{
${ }^{1}$ The authors thank Agnès Bénassy-Quéré, Jézabel Couppey-Soubeyran, Olena Havrylchyk and Valérie Mignon, as well as participants at the GdRE workshop on financial intermediation (Paris, April 2010) for helpful comments. The usual disclaimer applies.

${ }^{*}$ CES, Université Paris 1 Panthéon-Sorbonne \& CEPII. Email: gunther.capelle-blancard@univ-paris1.fr. Corresponding author: 106-112 Bd de l'hopital 75647 Paris Cedex 13 France. Phone:+33 (0)1 44078270.

$\dagger$ ENSAE ParisTech \& CEPII.
} 
Bolton et al. (2011) have examined theoretically the equilibrium size of the financial sector, while Goldin \& Katz (2008) or Philippon \& Reshef (2008) provide empirical evidence that the growth of the financial industry has attracted too many talents, to the detriment of others industries. $^{2}$ During the crisis, such concern was vividly expressed, in particular by Lord Turner, the chairman of the UK's Financial Services Authority, who declared in 2009 that the financial industry had grown "beyond a socially reasonable size".

In this paper, we reexamine empirically the finance/growth nexus. Compared to previous studies, we propose to gauge the size of the financial sector based on its inputs, rather than its outputs. More specifically, we consider two original variables: i) the number of employees in the financial sector divided by the total workforce and ii) the ratio private credit divided by the number of employees in the financial sector. Using the number of employees to assess the size of an industry is quite usual in the economic literature ${ }^{3}$, but strangely not in financial economics. Our two variables alleviate both the problems of excessive growth of credit and misallocation of talents. Moreover, our data have the advantage of being available over a long period (1970-2008) for a large sample (24 OECD countries). Hence, our results are directly comparable with the bulk of evidence on the finance-growth nexus. Our methodology relies on difference and system estimators defined by Arellano \& Bond (1991) and Blundell \& Bond (1998) as edited by Roodman (2009) in the context of growth equation estimation. It enables us to handle endogeneity with macroeconomic data. Our results confirms that there is no clear and positive relationship between finance and growth.

The remainder of this paper is organized as follows. Section 2 reviews financial sector measures and describes the data. Section 3 develops econometrics issues raised by growth equations and details our methodology to face them. Section 4 presents the results and section 5 concludes.

\section{MEASURING FINANCIAL DEEPENING}

In the finance-growth literature, the size of the financial sector is proxied by its outputs. Since the seminal paper by King \& Levine (1993), preferred measures have been: the ratio of the credits to the private sector to GDP, the ratio of liquid liabilities to GDP and the ratio of commercial banks credits to the sum of commercial and central banks credits. All these proxies implicitly assume quality is increasing with quantity.

Several attempts have been made recently to consider better proxies of financial deepening. Beck et al. (2009) distinguish bank lending to firms and to households, and show that only the former spurs economic growth. Hasan et al. (2009) focus on the quality of financial services thanks to a sophisticated measure of bank efficiency and show that it has a positive impact on regional growth, while credit volume has not. These results are very appealing but deserve further examination. In both papers, the "quality" of the data comes at the expense of the

\footnotetext{
${ }^{2}$ See also Tobin (1984) for a prophetic warning.

${ }^{3}$ For instance, it is common to use the number of engineers to gauge the pace of innovation.
} 
"quantity". The authors have no other choice but to rely on a very short period (1994-2005 for Beck et al. (2009) and 1996-2004 for Hasan et al. (2009)). This is a serious limitation: first, this period is not subject to a major banking crisis; second, the authors have to use annual growth rate with the risk of having a very noisy variable, or to compute growth rate on the whole period, but this strongly constrains the methodology (the number of observations is between 27 and 45 in Beck et al. (2009); Hasan et al. (2009) consider simple - but potentially flawed OLS estimations). To tackle this problem, Hasan et al. (2009) consider regional growth. This is a valuable contribution - provided that banking data can be properly distributed between regions. ${ }^{4}$ However, this does not facilitate the interpretation of the results since all previous papers consider countries.

In this paper, we propose two original variables to characterize financial deepening:

- The number of employees in the financial sector divided by the total workforce;

- The ratio private credit divided by the number of employees in the financial sector

The former accounts for the size of the financial workforce relative to the rest of the economy, while the latter is an output/input ratio, indicating performance. The logic of the last variable is similar to Hasan et al. (2009) as we consider that an increase in credit volume does not necessarily indicate financial deepening. Our measure of bank efficiency is quite basic, but is easily comparable with previous evidence on the finance-growth nexus.

We restrict our sample to OECD countries to limit heterogeneity issues (Favara (2009). ${ }^{5}$ We use Levine et al. (2000)'s database which offers the whole set of controls and the three traditional financial sector measures. We expand this database until 2008 thanks to Beck \& DemirgucKunt (2009), World Bank World Development Indicators and Barro \& Lee (2010). The number of employees is extracted from the OECD Structural Analysis for 24 countries between 1970 and 2008 .

We use alternatively two sets of controls as in Levine et al. (2000). The simple conditioning information set consists of a constant, initial GDP per capita (log), and initial level of human capital. This set is complemented with three other variables in the policy conditioning information set: inflation rate (plus one, log), government size (government expenses, log), and international trade openness (ratio of the sum of importations and exportations to GDP, $\log$ ).

\footnotetext{
${ }^{4}$ In the main part of the article, banks are allocated to regions on the basis of headquarters location. Then, the authors consider different robustness checks.

${ }^{5}$ Rioja \& Valev (2004) and Aghion et al. (2005) show that the effects of financial development on growth in high-income countries are smaller than in developing countries.
} 


\section{METHODOLOGY}

We estimate the following equation:

$$
y_{i t}=\alpha y_{i t-1}+\gamma F_{i t}+\beta^{\prime} x_{i t}+\eta_{i}+\lambda_{t}+\varepsilon_{i t}
$$

where $y_{i t}$ is the growth rate of GDP per capita, $F_{i t}$ is a measure of the financial sector (in logarithm) and $x_{i t}$ is a set of controls for country $i$ in period $t$. Country fixed effects $\eta_{i}$ capture differences in the initial level of efficiency. Time dummies $\lambda_{t}$ account for productivity changes common to all countries and time specific measurement errors. To avoid modeling cyclical dynamics, $t$ represents a five-year period (except 2005-2008).

Estimating $\gamma$, i.e. the impact of financial deepening on growth raises endogeneity issues: Is a country developed thanks to its state-of-the-art financial system or is the financial system at the state-of-the-art because the country is developed ? Since Levine et al. (2000), the finance/growth literature has backed its results on difference and system estimators defined by Arellano \& Bond (1991) and Blundell \& Bond (1998). Although these estimators manage endogeneity, Roodman (2009) warns against their systematical use. Because of vitiated tests, Levine et al. (2000) dynamic panel results might be spurious and cannot be considered as evidence to reject the hypothesis that finance does not cause growth. Accordingly, we follow Roodman (2009)'s approach (see in Appendix for technical details).

To check the validity of instruments and subsets of instruments, we test over-identifying restrictions thanks to the Hansen and Difference-in-Hansen tests. Because instrument proliferation vitiates the Hansen test (Roodman (2009)), we exclude estimation results whose p-values are abnormally high. Practically, we compute two estimators for two sets of controls (simple and policy). The simple set of controls certainly suffers from omitted variable bias. However the policy set risks instrument proliferation. Our beam of results aims at accounting for the tradeoff.

Loayza \& Ranciere (2005) warn about the importance of time horizon when studying the finance/growth nexus. Thanks to a pooled mean group estimation, they account for contrasting effects of finance on growth distinguishing short- and long-run effects. Using traditional variables, they conclude the long-run relationship between financial intermediation and economic activity is positive whereas its short-term counterpart is negative. Significantly negative shortterm effects are to be found in countries suffering from banking crises or high financial volatility while the effect is not significant for stable countries. System and difference estimators do not tackle this issue. They are intended to catch a long term effect since run on data averaged over 5-year periods, but nothing absolutely guarantees cycle effects are removed by this transformation. Do long term effects compensate short-term effects in our estimation, leading to irrelevant estimates ? To avoid blurred estimates, we follow Rousseau \& Wachtel (2011) methodology and add an interact variable (financial sector measure $\times$ crisis dummy) in our regression equation. To some extent, this allows to address time horizon problems since Loayza \& Ranciere (2005) 
found short-term effects appear only in unstable countries. We create a dummy that equals 1 if during any year of the five-year period the country suffers from a systemic banking crisis, a currency crisis or a debt crisis (Laeven \& Valencia (2010)).

\section{Results}

We estimate the model for 24 OECD countries between 1970 and 2008 using two-step system GMM. Table 1 summarizes the results of 20 different specifications: 5 measures of financial deepening ( 3 usual measures +2 original measures) $\times 2$ sets of control (policy + simple) $\times$ 2 states (with or without a crisis interaction). We present the estimated coefficients associated with the variables of interest (Private credit/GDP, Liquid Liabilities/GDP, Bank credit/Total credit), Number of employees in the financial sector/Total workforce, Private credit/Number of employees in the financial sector), along with the p-value of the Hansen test, Diff-in-Hansen test and Arellano-Bond test. ${ }^{6}$

Neither classical nor labour measures denote a robust effect of financial deepening on growth. ${ }^{7}$ The coefficients on Private credit/GDP and its interaction with a crisis dummy are never statistically significant. Results are identical for Liquid liability/GDP. The coefficient on Bank credit/Total credit is significant at $10 \%$ only with the policy set of controls and without a crisis interaction. However, results of the diff-in-Hansen and Arellano-Bond tests (abnormally high p-value) indicate significance to be unreliable. Employees/Workforce and Private credit/Employees are significant when interacted with a crisis dummy at 10\%, but only with the simple controls set. These estimations fail to pass the Hansen test.

Maybe these results suffer from a structural break in the 1980s due to the deregulation of the financial sector (Philippon \& Reshef (2008)). We drop the first ten years ${ }^{8}$ of the dataset to estimate the nexus for the period 1980-2008). Results are qualitatively unchanged. We fail to reject the null hypothesis that the size of the financial sector, as measured by labour input, does not cause growth.

Recently, Arcand et al. (2011) provide evidence of a threshold above which financial development no longer has a positive effect on economic growth. Thus, we test for such a non-linear effect. Our results are not significant or the models do not pass the usual specification tests (see Table 4 in appendix). This may be due to our more homogeneous sample of countries.

\footnotetext{
${ }^{6}$ Except government expenses, the control variables are not significant (see in appendix). This result may seem strange prima facie, but it is quite usual in this kind of approach, especially with a panel of developed countries. Similar results are obtained by Levine et al. (2000) or Arcand et al. (2011) for instance.

${ }^{7}$ To be sure our results are not driven by 2007 and 2008 observations, we run the estimators over periods ending in 2005. Results are qualitatively unchanged.

${ }^{8}$ Ideally, we should drop the first twenty years of the dataset to allow for structural change to have completely developed. We cannot because of the time length required by our estimator.
} 
Table 1 - Financial sector and growth: 1970-2008, 24 OECD countries

\begin{tabular}{ccccc}
\hline \hline Controls set & Policy & Simple & Policy & Simple \\
Instruments & 17 & 11 & 22 & 16 \\
\hline Private credit/GDP & -0.06 & 0.9 & -0.9 & -0.8 \\
$\times$ crisis & & & -0.12 & -0.24 \\
Hansen test & 0.178 & 0.139 & 0.719 & 0.482 \\
Diff-in-Hansen test: lagged growth & 0.094 & 0.742 & 0.127 & 0.870 \\
Arellano-Bond test & 0.867 & 0.892 & 0.692 & 0.528 \\
\hline Liquid Liabilities/GDP & 0.08 & 0.9 & -1.2 & 0.64 \\
$\times$ crisis & & & -0.2 & -0.37 \\
Hansen test & 0.426 & 0.320 & 0.709 & 0.281 \\
Diff-in-Hansen test: lagged growth & 0.021 & 0.302 & 0.111 & 0.844 \\
Arellano-Bond test & 0.582 & 0.552 & 0.469 & 0.390 \\
\hline Bank credit/Total credit & $6.7 *$ & 13.6 & 6.4 & 14.8 \\
$\times$ crisis & & & -0.20 & 0.14 \\
Hansen test & 0.945 & 0.181 & 0.753 & 0.179 \\
Diff-in-Hansen test: lagged growth & 0.949 & 0.048 & 0.181 & 0.092 \\
Arellano-Bond test & 0.978 & 0.985 & 0.839 & 0.998 \\
\hline Employees/Workforce & 0.3 & 4.5 & -0.9 & -1.4 \\
$\times$ crisis & & & 0.08 & $0.13 *$ \\
Hansen test & 0.560 & 0.260 & 0.692 & 0.022 \\
Arifing & 0.339 & 0.108 & 0.410 & 0.376 \\
Arellano-Bond test & 0.746 & 0.729 & 0.789 & 0.856 \\
\hline Private credit/Employees & -0.437 & -0.236 & 0.54 & 0.38 \\
$\times$ crisis & & & 0.36 & $0.74 * *$ \\
Hansen test & 0.388 & 0.023 & 0.646 & 0.007 \\
Arellano-Bond test & 0.753 & 0.441 & 0.563 & 0.581 \\
\hline \hline
\end{tabular}

Notes: All regressions are two-step collapsed System GMM. All variables are in logarithm. P-values are reported for tests. $* * *, * *, *$ significant at the $1 \%, 5 \%$, and $10 \%$ level respectively. 


\section{Conclusion}

The crisis called into question the commonly accepted measures to assess the growth of the financial sector. In this paper, we reexamine empirically the finance/growth nexus by using two original measures of financial deepening related to the number of employees in the financial sector. Our study confirms the absence of a positive relationship between financial deepening and GDP for OECD countries over the last forty years.

The share of employees working in banking and finance is a direct measure of the potential misallocation of talents. The ratio private credit to number of employees in the financial sector can alleviate the problem raised by an excessive growth of credit and unproductive financial deepening, although it cannot fully solve it. Usually, an increase of an output/input ratio is interpreted as an improvement of the economic process. But it is unclear wether an increase of private credit relative to the number of employees captures a higher ability of the financial sector to convert efficiently inputs into outputs. ${ }^{9}$ More research is needed to assess how the financial sector accomplishes its tasks.

\section{REFERENCES}

Aghion, P., Howitt, P., \& Mayer-Foulkes, D. (2005). The effect of financial development on convergence: Theory and evidence. Quarterly Journal of Economic, 120, 173-222.

Arcand, J.-L., Berkes, E., \& Panizza, U. (2011). Too much finance? Working Paper.

Arellano, M. \& Bond, S. (1991). Some tests of specification for panel data: Monte carlo evidence and an application to employment equations. The Review of Economic Studies, 58, 277-297.

Barro, R. \& Lee, J. (2010). A new data set of educational attainment in the world: 1950-2010. NBER Working Paper, 15902.

Baumol, W. J. (1990). Entrepreneurship: Productive, unproductive and destructive. Journal of Political Economy, 98, 893-921.

Beck, T., Beyekkarabacak, B., Rioja, F., \& Valev, N. (2009). Who gets the credit? and does it matter? household vs. firm lending across countries. CEPR Working Paper 7400.

Beck, T. \& Demirguc-Kunt, A. (2009). Financial institutions and markets across countries and over time - data and analysis. World Bank Policy Research Working Paper, 4943.

Blundell, R. \& Bond, S. (1998). Initial conditions and moment restrictions in dynamic panel data models. Journal of Econometrics, 87, 115-143.

Bolton, P., Santos, T., \& Scheinkman, J. A. (2011). Cream skimming in financial markets. NBER Working Paper, 16804.

Bordo, M. D. \& Rousseau, P. L. (2011). Historical evidence on the finance-trade-growth nexus. NBER Working Paper, 17024.

\footnotetext{
${ }^{9}$ The literature on medicine is also interested in the impact of the number of doctors. Interestingly, empirical evidence suggest that during episodes of doctors' strikes, mortality decreases (Cunningham et al. (2008)).
} 
Cunningham, S. A., Mitchell, K., Narayan, K. V., \& Yusuf, S. (2008). Doctors' strikes and mortality : A review. Social Science \& Medicine, 67(11), 1784-1788.

Favara, G. (2009). An empirical reassessment of the relationship between finance and growth. Working Paper, HEC University of Lausanne.

Goldin, C. \& Katz, L. (2008). Transitions: Career and family life cycles of the educational elite. American Economic Review, 98(2), 263-269.

Hasan, I., Koetter, M., \& Wedow, M. (2009). Regional growth and finance in europe: is there a quality effect of bank efficiency? Journal of Banking and Finance, 33(8), 1446-1453.

King, R. \& Levine, R. (1993). Finance and growth: Schumpeter might be right. Quaterly Journal of Economics, 108-3, 717-37.

Laeven, L. \& Valencia, F. (2010). Resolution of banking crises: The good, the bad, and the ugly. IMF Working Paper, 10/146.

Levine, R. (2005). Finance and growth: Theory and evidence. Handbook of Economic Growth, 1.

Levine, R., Loayza, N., \& Beck, T. (2000). Financial intermediation and growth: Causality and causes. Journal of Monetary Economics, 46, 31-77.

Loayza, N. \& Ranciere, R. (2005). Financial development, financial fragility and growth. IMF Working Papers, 05/170.

Manning, M. J. (2003). Finance causes growth: Can we be so sure? The B.E. Journal of Macroeconomics, 3.

Murphy, K. M., Shleifer, A., \& Vishny, R. W. (1991). The allocation of talent: Implications for growth. Quarterly Journal of Economics, 16(2).

Philippon, T. (2009). The evolution of the us financial industry from 1860 to 2007. NYU Working Paper.

Philippon, T. \& Reshef, A. (2008). Wages and human capital in the u.s. financial industry:1909-2006. NBER Working Paper, 14644.

Rioja, F. \& Valev, N. (2004). Does one size fit all? a reexamination of the finance and growth relationship. Journal of Development Economics, 74(2), 429-447.

Roodman, D. (2006). How to do xtabond2: An introduction to "difference" and "system" gmm in stata. Center for Global Development Working Paper, 103.

Roodman, D. (2009). A note on the theme of too many instruments. Oxford Bulletin of Economics and Statistics, 71, 135-158.

Rousseau, P. L. \& Wachtel, P. (2002). Inflation thresholds and the finance-growth nexus. Journal of International Money and Finance, 21, 777-793.

Rousseau, P. L. \& Wachtel, P. (2011). What is happening to the impact of financial deepening on economic growth? Economic Inquiry, 49(1), 276-288.

Tobin, J. (1984). On the efficiency of the financial system. Lloyds Bank Review, 153, 1-15.

Wachtel, P. (2003). How much do we really know about growth and finance? Economic Inquiry, 88, 33-47. 


\section{APPENDiX.}

\section{A. Methodology}

To estimate $\gamma$, we consider a linear autoregressive dynamic panel data model:

$$
\begin{gathered}
y_{i t}=\alpha y_{i t-1}+\gamma F_{i t}+\beta^{\prime} x_{i t}+u_{i t} \\
u_{i t}=\eta_{i}+\nu_{i t}
\end{gathered}
$$

for $i=1, \ldots, N$ and $t=2, \ldots . T$. We assume $N$ large, $T$ fixed and $|\alpha|<1$. We apply the estimation procedure proposed by Arellano \& Bond (1991).

We make the following assumptions:

- $\mathbf{E}\left(\eta_{i}\right)=0$

- $\mathbf{E}\left(\nu_{i t}\right)=0$

- $\mathbf{E}\left(\nu_{i t} \eta_{i}\right)=0$ for $i=1, \ldots, N$ and $t=2, \ldots . T$

- $\mathbf{E}\left(\nu_{i t} \nu_{i s}\right)=0$ for $i=1, \ldots, N$ and $\forall t \neq s$

- $\mathbf{E}\left(y_{i 1} \nu_{i t}\right)=0$ for $i=1, \ldots, N$ and $t=2, \ldots, T$.

We test these assumptions thanks to Arellano-Bond tests. Arellano \& Bond (1991) device tests of errors autocorrelation. For $T \geq 5$, Arellano \& Bond (1991) define a statistic for the test whose null hypothesis is:

$$
H_{0}^{2}: \mathbf{E}\left(v_{i t}^{D} v_{i t-2}^{D}\right)=0 .
$$

where $v_{i t}^{D}$ is the first-order difference of $v_{i t}$. The model is valid if this hypothesis cannot be rejected. Such an assumption is valid in two cases:

- if errors in level are not serially correlated: $\mathbf{E}\left(v_{i t} v_{i t-1}\right)=0(1)$;

- if $\nu_{i t}$ is a randow walk (2).

To distinguish between these two situations, one can test for first-order correlation since:

$$
H_{0}^{1}: \mathbf{E}\left(v_{i t}^{D} v_{i t-1}^{D}\right)=0 \Rightarrow(1) .
$$

Such test is interesting since defined for $T \geq 4$. In this case, if the model passes the $H_{0}^{1}$ test, it would pass the $H_{0}^{2}$ test, which is not defined here. Nonetheless, failing the $H_{0}^{1}$ test does not mean failing the $H_{0}^{2}$ test.

These conditions imply the moment restrictions:

$$
\mathbf{E}\left(Z_{d i}^{\prime} \Delta u_{i}\right)=0
$$


with $\Delta u_{i}{ }^{10}$ the $(T-2)$ vector $\left(\Delta u_{i 3}, \ldots, \Delta u_{i T}\right)^{\prime}$ and $Z_{d i}^{\prime}$ the $(T-2) \times 0.5(T-1)(T-2)$ matrix defined as:

$$
Z_{d i}^{\prime}=\left(\begin{array}{ccccccc}
y_{i 1} & 0 & 0 & \ldots & 0 & \ldots & 0 \\
0 & y_{i 1} & y_{i 2} & \ldots & 0 & \ldots & 0 \\
\ldots & \ldots & \ldots & \ldots & \ldots & \ldots & \ldots \\
0 & 0 & 0 & \ldots & y_{i 1} & \ldots & y_{i T-2}
\end{array}\right)
$$

The GMM estimator weights the moment restrictions thanks to $W_{N}$ to estimate $\left(\alpha, \gamma, \beta^{\prime}\right)$ as the set of parameters that minimizes the distance $\Delta u^{\prime} Z_{d} W_{N} Z_{d}^{\prime} \Delta u$ with $Z_{d}^{\prime}=\left(Z_{d 1}^{\prime}, \ldots, Z_{d N}^{\prime}\right)$ and $\Delta u^{\prime}=$ $\left(\Delta u_{1}^{\prime}, \ldots, \Delta u_{N}^{\prime}\right)$.

We follow a two-step estimation procedure that optimizes $W_{N}=\left(\frac{1}{N} \sum_{i} Z_{d i}^{\prime} \widehat{\Delta u}_{i} \widehat{\Delta u}_{i}^{\prime} Z_{d i}\right)^{-1}$ (where $\widehat{\Delta u}_{i}$ are residuals from an initial consistent estimator) to get an asymptotically efficient estimator.

This raises two issues. $W_{N}$ estimates tend to be quite imprecise since they rely on fourth moments of the random variables observed (Roodman (2009)). Besides, to avoid biased inference, we use Windjmeijer's correction for standard errors.

We have defined the difference estimator. Nonetheless, our dependent variable - growth - is very persistent. Blundell \& Bond (1998) demonstrated that first differences are weak instruments for equation in levels in this case. We have to turn to additional restrictions to define the system estimator:

$$
\mathbf{E}\left(u_{i 3} \Delta y_{i 2}\right)=0 .
$$

A sufficient condition for this moment restriction to hold is mean stationarity ${ }^{11}$ (Blundell \& Bond (1998)). Since we control for time fixed effects, the condition is verified.

To compute the system estimator, we replace $Z_{d i}^{\prime}$ in the precedent procedure by the following $Z_{d i}^{\prime+}$ :

$$
Z_{d i}^{\prime+}=\left(\begin{array}{ccccc}
Z_{d i}^{\prime} & 0 & 0 & \ldots & 0 \\
0 & \Delta y_{i 2} & 0 & \ldots & 0 \\
\ldots & \ldots & \ldots & \ldots & \ldots \\
0 & 0 & 0 & \ldots & \Delta y_{i T-1}
\end{array}\right)
$$

For both estimators, the number of instruments is quadratic in $T$. As emphasized by Roodman (2009), using too many instruments overfits endogenous variables. To limit the instrument count, we limit the number of lags and collapse the instrument matrices. That is to say we use respectively $Z_{d i}^{c}$ and $Z_{d i}^{\prime+c}$ as instrument matrices (Roodman (2006)).

\footnotetext{
${ }^{10}$ We removed fixed effects by first differencing.

${ }^{11}$ The necessary condition is that the deviations of the initial conditions from $\eta_{i} /(1-\alpha)$ are uncorrelated with the level of $\eta_{i} /(1-\alpha)$.
} 


$$
Z_{d i}^{c}=\left(\begin{array}{ccccc}
y_{i 1} & 0 & 0 & \ldots & 0 \\
y_{i 2} & y_{i 1} & 0 & \ldots & 0 \\
y_{i 3} & y_{i 2} & y_{i 1} & \ldots & 0 \\
\ldots & \ldots & \ldots & \ldots & \ldots \\
\ldots & \ldots & \ldots & \ldots & \ldots \\
\ldots & \ldots & \ldots & \ldots & \ldots
\end{array}\right) Z_{d i}^{\prime+c}=\left(\begin{array}{cc}
Z_{d i}^{\prime c} & 0 \\
0 & \Delta y_{i 2} \\
0 & \Delta y_{i 3} \\
\ldots & \ldots \\
0 & \Delta y_{i T-1}
\end{array}\right)
$$

See table 2 for reproduction of Levine et al. (2000) results taking into account Roodman (2009) methodology.

Since Rousseau \& Wachtel (2002) detected the finance-growth nexus was sensitive to inflation, research has focused on the variability of this relationship. Rousseau \& Wachtel (2011) stressed a decline of the impact of financial deepening on economic growth since the 1990s. Indeed, when we estimate with Roodman (2009) methodology the finance-growth nexus on Levine et al. (2000)'s database but restricted to 1960-1980, private credit - Levine et al. (2000) preferred measure - is significant both statistically and economically (see table 2). Thus, studying a more recent period means looking for a declining finance impact on growth.

Table 2 - Reproduction of Levine et al. (2000) results

\begin{tabular}{ccccccc}
\hline \hline Period & \multicolumn{3}{c}{$1960-1995$} & \multicolumn{3}{c}{$1960-1980$} \\
Estimator & \multicolumn{2}{c}{ System } & Difference & \multicolumn{2}{c}{ System } & Difference \\
Controls set & Policy & Simple & Policy & Policy & Simple & Policy \\
$N$ & & 74 & & & 69 & \\
Instruments & 19 & 11 & 40 & 16 & 8 & 16 \\
\hline Private credit & $2.3^{*}$ & 1.3 & 0.8 & 3.4 & 1.8 & $4.13^{*}$ \\
Hansen test & 0.013 & 0.609 & 0.131 & 0.242 & 0.750 & 0.509 \\
Diff-in-Hansen test: lagged growth & 0.000 & 0.576 &. & 0.037 & 0.610 &. \\
Arellano-Bond test & 0.899 & 0.561 & 0.839 & 0.028 & 0.019 & 0.340 \\
\hline Liquid Liability & $4.5^{*}$ & 2.0 & -0.1 & $8.7^{*}$ & 2.7 & 4.9 \\
Hansen test & 0.200 & 0.468 & 0.108 & 0.813 & 0.960 & 0.572 \\
Diff-in-Hansen test: lagged growth & 0.033 & 0.998 &. & 0.897 & 0.785 &. \\
Arellano-Bond test & 0.931 & 0.562 & 0.534 & 0.044 & 0.014 & 0.514 \\
\hline Bank credit / Total credit & 3.0 & 0.7 & 2.7 & 3.6 & 5.3 & 3.1 \\
Hansen test & 0.062 & 0.406 & 0.330 & 0.045 & 0.543 & 0.488 \\
Diff-in-Hansen test: lagged growth & 0.001 & 0.183 &. & 0.012 & 0.383 &. \\
Arellano-Bond test & 0.480 & 0.526 & 0.461 & 0.052 & 0.011 & 0.928 \\
\hline
\end{tabular}

Notes: * significant at 5\%. P-values are reported for tests. Private credit fails to pass the Fisher test for the system estimator with the simple controls set (p-value: 0.05). Since $T=4$ for 1960-1980, we report Arellano-Bond test for first-differenced errors correlation at the first order, as explained in the previous section. 
B. Additional tables

- Table 3: 'Full' regressions: 1970-2008, 24 OECD countries

- Table 4: Nonlinear regressions: 1970-2008, 24 OECD countries 


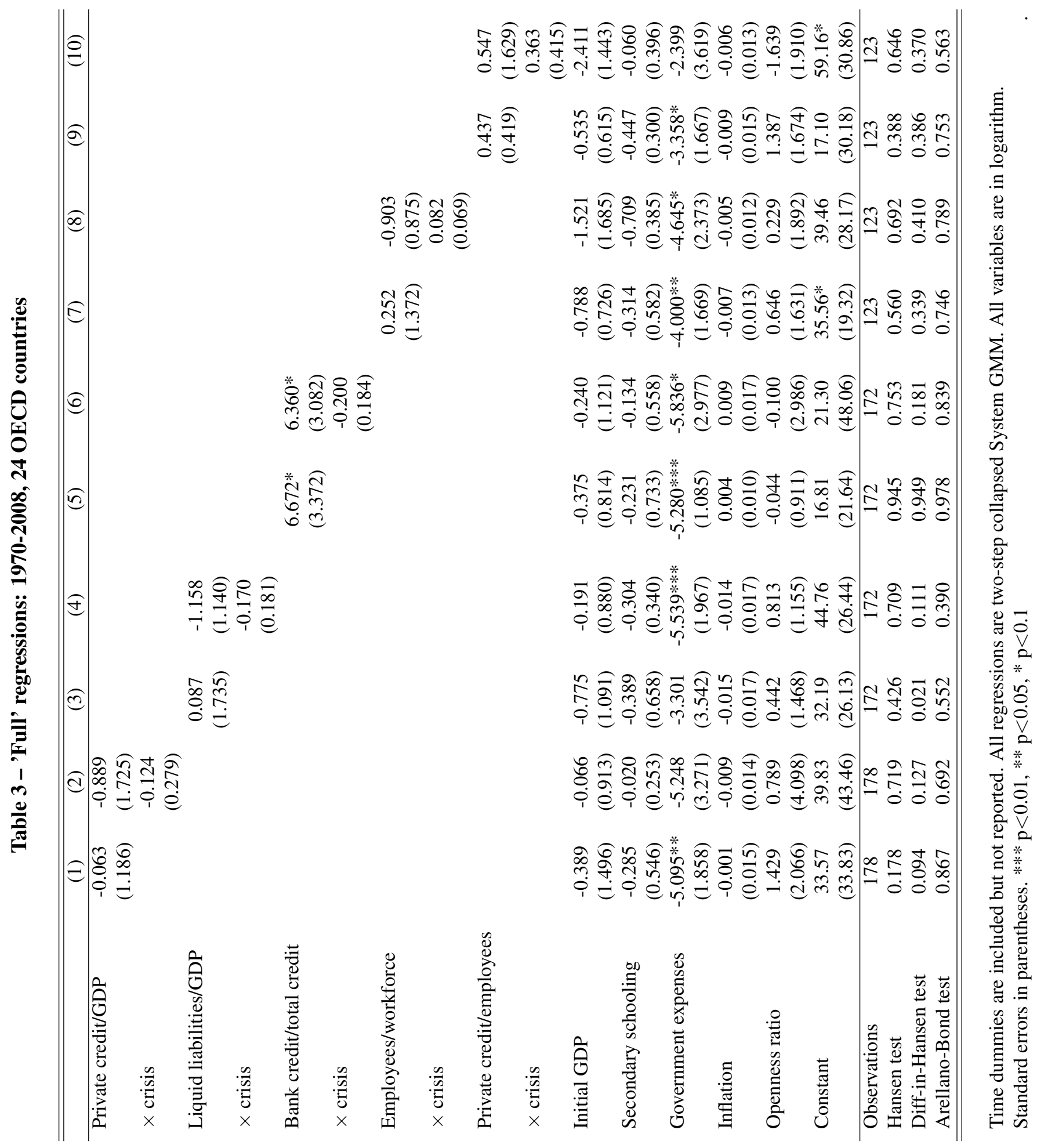


Table 4 - Nonlinear regressions: 1970-2008, 24 OECD countries

\begin{tabular}{lcccc}
\hline \hline & $(1)$ & $(2)$ & $(3)$ & $(4)$ \\
& Policy & Simple & Policy & Simple \\
\hline Private credit/GDP & $18.50^{*}$ & -17.41 & & \\
& $(10.71)$ & $(26.24)$ & & \\
(Private credit/GDP) $^{2}$ & $-2.489^{*}$ & 2.231 & & \\
& $(1.238)$ & $(3.208)$ & & \\
Employees/Workforce & & & -8.387 & -30.52 \\
& & & $(8.684)$ & $(30.59)$ \\
(Employees/Workforce $)^{2}$ & & & 3.611 & 13.09 \\
& & & $(3.687)$ & $(13.10)$ \\
Initial GDP & $3.126^{*}$ & $-3.741^{* *}$ & -0.232 & 0.0530 \\
& $(1.605)$ & $(1.382)$ & $(0.845)$ & $(2.025)$ \\
Secondary schooling & -0.471 & 0.0932 & -0.121 & 0.0466 \\
& $(0.373)$ & $(0.680)$ & $(0.331)$ & $(0.701)$ \\
Government expenses & $-5.846^{*}$ & & $-4.005^{* *}$ & \\
& $(3.052)$ & & $(1.601)$ & \\
Inflation & 0.0336 & & -0.0119 & \\
& $(0.0208)$ & & $(0.0167)$ & \\
Openness & $2.079^{* *}$ & & -0.738 & \\
& $(0.952)$ & & $(1.548)$ & \\
Constant & -33.17 & 71.19 & $45.86^{* *}$ & 16.17 \\
& $(24.84)$ & $(60.53)$ & $(20.16)$ & $(13.28)$ \\
\hline Observations & 178 & 178 & 123 & 123 \\
AB test & 0.859 & 0.883 & 0.760 & 0.472 \\
Hansen test & 0.713 & 0.314 & 0.489 & 0.981 \\
Diff-in-Hansen test & 0.809 & 0.883 & 0.589 & 0.969 \\
\hline \hline
\end{tabular}

Time dummies are included but not reported. All regressions are two-step collapsed System GMM. All variables are in logarithm. Standard errors in parentheses. ${ }^{* * *} \mathrm{p}<0.01,{ }^{* *} \mathrm{p}<0.05,{ }^{*} \mathrm{p}<0.1$ 


\section{LIST OF WORKING PAPERS RELEASED BY CEPII}

An exhaustive list is available on the website: \www.cepii.fr.

No

Title

Authors

2011-21 EMU, EU, Market Integration and Consumption Smoothing

2011-20 Real Time Data and Fiscal Policy Analysis

J. Cimadomo

2011-19 On the inclusion of the Chinese renminbi in the SDR basket
A. Bénassy-Quéré \& D. Capelle

2011-18 Unilateral trade reform, Market Access and Foreign Competition: the Patterns of Multi-Product Exporters

2011-17 The "Forward Premium Puzzle" and the Sovereign Default Risk

2011-16 Occupation-Eduction Mismatch of Immigrant Workers in Europe: Context and Policies

M. Aleksynska \& A. Tritah

2011-15 Does Importing More Inputs Raise Exports? Firm Level Evidence from France

M. Bas \& V. Strauss-Kahn

2011-14 Joint Estimates of Automatic and Discretionary Fiscal Policy: the OECD 1981-2003

J. Darby \& J. Mélitz

2011-13 Immigration, vieillissement démographique et financement de la protection sociale : une évaluation par l'équilibre général calculable appliqué à la France

2011-12 The Performance of Socially Responsible Funds: Does the Screening Process Matter?

G. Capelle-Blancard \& S. Monjon

2011-11 Market Size, Competition, and the Product Mix of Exporters

T. Mayer, M. Melitz \& G. Ottaviano

2011-10 The Trade Unit Values Database

A. Berthou \& C. Emlinger 
No

Title

2011-09 Carbon Price Drivers: Phase I versus Phase II Equilibrium

2011-08 Rebalancing Growth in China: An International Perspective

2011-07 Economic Integration in the EuroMed: Current Status and Review of Studies

2011-06 The Decision to Import Capital Goods in India: Firms' Financial Factors Matter

2011-05 FDI from the South: the Role of Institutional Distance and Natural Resources

2011-04b What International Monetary System for a fastchanging World Economy?

2011-04a Quel système monétaire international pour une économie mondiale en mutation rapide?

2011-03 China's Foreign Trade in the Perspective of a more Balanced Economic Growth

2011-02 The Interactions between the Credit Default Swap and the Bond Markets in Financial Turmoil

2011-01 Comparative Advantage and Within-Industry Firms Performance

2010-33 Export Performance and Credit Constraints in China

2010-32 Export Performance of China's domestic Firms: The Role of Foreign Export Spillovers

2010-31 Wholesalers in International Trade

2010-30 TVA et taux de marge : une analyse empirique sur données d'entreprises

2010-29 Economic and Cultural Assimilation and Integration of Immigrants in Europe

\section{Authors}

A. Creti, P.-A. Jouvet \& V. Mignon

A. Bénassy-Quéré, B. Carton \& L. Gauvin

J. Jarreau

A. Berthou \& M. Bas

M. Aleksynska \& O. Havrylchyk

A. Bénassy-Quéré \& J. Pisani-Ferry

A. Bénassy-Quéré \& J. Pisani-Ferry

G. Gaulier, F. Lemoine \& D. Ünal

V. Coudert \& M. Gex

M. Crozet \& F. Trionfetti

J. Jarreau \& S. Poncet

F. Mayneris \& S. Poncet

M. Crozet, G. Lalanne \& S. Poncet P. Andra, M. Carré \& A. Bénassy-Quéré

M. Aleksynska \& Y. Algan 
No

Title

2010-28 Les firmes françaises dans le commerce de service

2010-27 The world Economy in 2050: a Tentative Picture

2010-26 Determinants and Pervasiveness of the Evasion of Customs Duties

2010-25 On the Link between Credit Procyclicality and Bank Competition

2010-24 Are Derivatives Dangerous? A Literature Survey

2010-23 BACI: International Trade Database at the ProductLevel - The 1994-2007 Version

2010-22 Indirect Exporters

2010-21 Réformes des retraites en France : évaluation de la mise en place d'un système par comptes notionnels

2010-20 The Art of Exceptions: Sensitive Products in the Doha Negotiations

2010-19 Measuring Intangible Capital Investment: an Application to the "French Data"

2010-18 Clustering the Winners: The French Policy of Competitiveness Clusters

2010-17 The Credit Default Swap Market and the Settlement of Large Defauts

2010-16 The Impact of the 2007-10 Crisis on the Geography of Finance

2010-15 Socially Responsible Investing: It Takes more than Words
Authors

G. Gaulier, E. Milet \& D. Mirza

J. Fouré, A. Bénassy-Quéré \& L. Fontagné

S. Jean

\& C. Mitaritonna

V. Bouvatier, A. Lopez-Villavicencio \& V. Mignon

G. Capelle-Blancard

G. Gaulier \& Soledad Zignago

F. McCann

X. Chojnicki \& R. Magnani

C. Gouel, C. Mitaritonna \& M.P. Ramos V. Delbecque \& L. Nayman

L. Fontagné, P. Koenig, F. Mayneris \&S. Poncet

V. Coudert \& M. Gex

G. Capelle-Blancard \& Y. Tadjeddine

G. Capelle-Blancard \& S. Monjon 
No

Title

2010-14 A Case for Intermediate Exchange-Rate Regimes

2010-13 Gold and Financial Assets: Are they any Safe Havens in Bear Markets?

2010-12 European Export Performance

2010-11 The Effects of the Subprime Crisis on the Latin American Financial Markets: An Empirical Assessment

2010-10 Foreign Bank Presence and its Effect on Firm Entry and Exit in Transition Economies

2010-09 The Disorted Effect of Financial Development on International Trade Flows

2010-08 Exchange Rate Flexibility across Financial Crises

2010-07 Crises and the Collapse of World Trade: The Shift to Lower Quality

2010-06 The heterogeneous effect of international outsourcing on firm productivity

2010-05 Fiscal Expectations on the Stability and Growth Pact: Evidence from Survey Data

2010-04 Terrorism Networks and Trade: Does the Neighbor Hurt

2010-03 Wage Bargaining and the Boundaries of the Multinational Firm

2010-02 Estimation of Consistent Multi-Country FEERs

2010-01 The Elusive Impact of Investing Abroad for Japanese Parent Firms: Can Disaggregation According to FDI Motives Help

\section{Authors}

V. Salins

\& A. Bénassy-Quéré

V. Coudert \& H. Raymond

A. Cheptea, L. Fontagné \& S. Zignago

G. Dufrénot, V. Mignon \& A. Péguin-Feissolle

O. Havrylchyk

A. Berthou

V. Coudert, C. Couharde \& V. Mignon

A. Berthou \& C. Emlinger

Fergal McCann

M. Poplawski-Ribeiro \& J.C. Rüle

J. de Sousa, D. Mirza \& $\mathrm{T}$. Verdier

M. Bas \& J. Carluccio

B. Carton \& K. Hervé

L. Hering, T. Inui $\&$ S. Poncet 
Organisme public d'étude et de recherche en économie internationale, le CEPII est placé auprès du Centre d'Analyse Stratégique. Son programme de travail est fixé par un conseil composé de responsables de l'administration et de personnalités issues des entreprises, des organisations syndicales et de l'Université.

Les documents de travail du CEPII mettent à disposition du public professionnel des travaux effectués au CEPII, dans leur phase d'élaboration et de discussion avant publication définitive. Les documents de travail sont publiés sous la responsabilité de la direction du CEPII et n'engagent ni le conseil du Centre, ni le Centre d'Analyse Stratégique. Les opinions qui y sont exprimées sont celles des auteurs.

Les documents de travail du CEPII sont disponibles sur le site : http//www.cepii.fr. 